\title{
Does Manufacturing Agglomeration Promote Or Hinder Green Development Efficiency? Evidence From Yangtze River Economic Belt, China
}

Huaxi Yuan ( $\square$ huaxi@zuel.edu.cn )

Zhongnan University of Economics and Law https://orcid.org/0000-0002-4483-3659

Longhui Zou

Kent State University

Yidai Feng

Nanchang University

Lei Huang

Southwest University

\section{Research Article}

Keywords: manufacturing agglomeration, green development efficiency, instrumental variable,

Posted Date: December 29th, 2021

DOI: https://doi.org/10.21203/rs.3.rs-1123875/v1

License: (9) This work is licensed under a Creative Commons Attribution 4.0 International License.

Read Full License 
Title Page

\title{
Does Manufacturing Agglomeration Promote Or Hinder Green Development Efficiency? Evidence From Yangtze River Economic Belt, China
}

\author{
Huaxi Yuan ${ }^{\text {a* }}$ Longhui Zou ${ }^{\text {b }}$, Yidai Feng ${ }^{\text {c, }}{ }^{\text {, Lei Huang }}{ }^{\text {e }}$ \\ a School of Economics, Zhongnan University of Economics and Law, Wuhan 430073, China \\ ${ }^{\mathrm{b}}$ Department of Modern \& Classical Language Studies, Kent State University, Kent 44240, USA \\ c School of Economic \& Management, Nanchang University, Nanchang 330031, China \\ ${ }^{\mathrm{d}}$ Department of City and Regional Planning, University of North Carolina at Chapel Hill, Chapel Hill 27599, USA \\ e College of Economics and Management, Southwest University, Chongqing 400715, China.
}

\begin{abstract}
Sustainable development can be mainly achieved by promoting the green transformation and development of the world economy and by improving the efficiency of regional green development, which often receive extensive attention from the academia. This paper uses a spatial econometric model to estimate the impact of manufacturing agglomeration on green development efficiency based on the panel data of China's Yangtze River Economic Belt (YREB). The results show an overall large gap of green development efficiency between regions in the Yangtze River Economic Zone, mostly due to the extremely uneven development of green development efficiency in the upper reaches. Opposite to the middle and lower reaches, manufacturing agglomeration in the upper reaches of the YREB improves green development efficiency. Manufacturing agglomeration is conducive to the improvement of green development efficiency in neighboring areas. Nonetheless, it may hinder green development efficiency by inhibiting green technological innovation. This paper provides empirical evidence and policy implications for applying manufacturing agglomeration to promote green development efficiency in accordance with local conditions.
\end{abstract}

\section{Highlights}

- How manufacturing agglomeration (MA) affects green development efficiency (GDE).

- MA would hinder the improvement of GDE in China's YREB.

- MA would hinder the improvement of GDE by inhibiting green technological progress.

- There is a significant regional heterogeneity in the impact of MA on GDE.

- MA has a positive spillover on the GDE of neighboring areas.

Keywords: manufacturing agglomeration; green development efficiency; instrumental variable;

\footnotetext{
${ }^{*}$ Corresponding author. Huaxi Yuan, School of Economics, Zhongnan University of Economics and Law, Wuhan 430073, China. E-mail addresses: huaxi@zuel.edu.cn (H. Yuan) 
Yangtze River Economic Belt

Word Count: 8286

\section{Declarations}

Ethics approval and consent to participate

Not applicable.

\section{Consent for publication}

Not applicable.

\section{Availability of data and materials}

The data in this paper comes from the China City Statistical Yearbook and the China Economic

\section{Competing interests}

The authors declare that they have no competing interests.

\section{Funding}

This study was funded by Major Program of National Social Science Foundation of China (18ZDA047); Major program of the key research base of Humanities and Social Science Fund of Ministry of Education of China (17JJD790011).

\section{Authors' contributions}

This collaboration work was carried out by all the authors. Huaxi Yuan contributed to the study conception and design. Material preparation, data collection and analysis were performed by Huaxi Yuan. The first draft of the manuscript was written by Huaxi Yuan and Longhui Zou. Yidai Feng supervised and reviewed the manuscript. Lei Huang provided critical review. All authors commented on previous versions of the manuscript. All authors read and approved the final manuscript.

\section{Acknowledgements}

Not applicable. 


\section{Text}

\section{Does Manufacturing Agglomeration Promote or Hinder Green}

\section{Development Efficiency? Evidence from the Yangtze River}

\section{Economic Belt, China}

\section{Introduction}

Since China joined the World Trade Organization (WTO), economic growth has continued to propagate at a high level, but it has also brought serious environmental problems. Cai et al. (2018) (Wang et al., 2020; Yin et al., 2021), but also threatens the physical and mental health of human beings (Hong et al., 2020; Xing et al., 2020). In 2021, China's fourteenth five-year plan for national economic and social development lists green development as a major strategic planning task, which will guide China's economic and social development in the future. The key to promoting green development lies in improving green development efficiency, which refers to the input-output efficiency of the socioeconomic system concerning the undesirable output of energy consumption and pollutant emission (Shuai and Fan, 2020; Zhu et al., 2019). An important way to improve it would be targeting international and advanced standards to promote manufacturing agglomeration (Aleksandrova et al., 2020; Fang et al., 2020).

Manufacturing enterprises have contributed $32 \%$ of the GDP and $12 \%$ of the global goods exports to the Chinese economy (World Bank, 2017), but at the same time caused huge energy consumption and environmental pollution. Theoretically speaking, environmental quality deteriorates in the early stage of economic development and improves when economic development reaches to a certain level (Erdogan, 2020; Sarkodie and Ozturk, 2020). However, this seems inconsistent with the reality of China. By the end of $2019,61.03 \%$ of the manufacturing enterprises have agglomerated in Eastern China. They have absorbed $57.22 \%$ of the assets and contributed $58.55 \%$ of the profits of manufacturing enterprises. Moreover, their total power consumption accounted for $50.53 \%$ of the country's total, and their investment in industrial pollution control accounted for $53.22 \%$ of the country's total ${ }^{\mathbb{D}}$. This raises the following research questions that have

\footnotetext{
(1) The raw data comes from the 2020 China Statistical Yearbook.
} 
been barely studied in the existing literature: how does manufacturing agglomeration influence green development efficiency? Are there any patterns of the influence?

Compared to the previous research, this article attempts to integrate manufacturing agglomeration and green development efficiency into a unified analytic framework and investigate the relationship between the two, both theoretically and empirically. Besides, the Slack Based Measure (SBM) model is used to measure the green development efficiency under the constraints of energy and environment from the perspective of multi-input and multi-output, which may lead to more practical conclusion. Furthermore, the trade ports opened in the Qing Dynasty from 1842 to 1909 are adopted as an instrumental variable for manufacturing agglomeration, which might effectively mitigate the estimation bias caused by endogenous problems.

In the remainder of the article, we provide a brief literature review in Section 2, conception framework in Section 3, and research design in Section 4. We present the empirical results in Section 5 and discuss the research conclusions and policy recommendations in Section 6.

\section{Literature Review}

\subsection{Measurement of Green Development Efficiency}

Green development efficiency is mainly measured by parametric and non-parametric analysis methods. The parametric analysis method is represented by Stochastic Frontier Analysis (SFA), and the non-parametric analysis method is represented by Data Envelopment Analysis (DEA). The biggest advantage of SFA is that it can exclude the inefficiency term and random error term, thereby ensuring the effectiveness and consistency of the effect estimation. However, SFA is only applicable to the data sets with multi-input and single output (Klein et al., 2020; Liu et al., 2020). As for the DEA method, the significant advantage is that there is no need to set a specific production function in advance, which prevents possible deviation caused by mistaken setting. However, its production process cannot be fully described (Charnes et al., 1978; Huang et al., 2021). Since green development efficiency is a multi-input and multi-output process, it is unrealistic to forcibly adopt undesirable output indicators such as pollution emission as input variables. Previous research on the measurement of green development efficiency mainly focuses on the following two aspects: 
First, the development of measurement methods. The application of measurement models can

120 be roughly divided into four stages.

In the first stage, the undesirable output variable (pollutant emission) is used as an input variable. Mohtadi (1996) first introduced pollutant emission as an input variable into the traditional DEA model. Later, some scholars included both pollution emission and energy consumption as input variables into the DEA model for estimation (Korhonen and Luptacik, 2004; Ramanathan, 2005).

In the second stage, the Directional Distance Function (DDF) model is applied. Chung et al. (1997) first proposed the DDF model in 1997, and successfully separated desirable output from undesirable output. Managi and Kumar (2009) further adopted the DDF model to set regional GDP as desirable output and sulfur dioxide and carbon dioxide emissions as undesirable output, measuring technological changes in 76 countries from 1963 to 2000. Lin and Benjamin (2017) then used non-radial DDF model to estimate the green development status of Chinese provincial regions. In the third stage, the SBM model and the DDF model are integrated. Since the traditional DEA model cannot identify the slack variable of invalid DMU, the efficiency of the undesirable output cannot be accurately calculated. To solve the slack variable problems of desirable and undesirable outputs, Tone (2001) proposed the SBM model. The SBM model allows input and output to change by different proportions and is not subject to the input or output perspective. Furthermore, Chen et al. (2019) and Yuan et al. (2020) used the SBM-DFF model to measure China's green development efficiency from provincial and municipal scales.

In the fourth stage, the Super SBM-DFF model is adopted. Although the SBM-DFF model has resolved the issues of directivity and slackness, it cannot distinguish and sort effective units. To this end, Tone (2002) proposed the Super SBM-DFF model, which can better sort DMU and reflect the difference in green development efficiency more realistically. Moreover, Zhu et al. (2019) used the Super SBM-DFF model to measure the green development efficiency of China's provinces.

Second, Expansion of input and output variables.

Most studies seem to have a relatively narrow range of input and output selections when analyzing green development efficiency. They only take capital and labor into account for input variables, and economic output and industrial pollutant emission for output variables (Zhang et al., 2018). However, with the economic and social development, new elements such as energy, resources and technology have become increasingly prominent, and the proportion of undesirable output such 
as PM2.5, chemical oxygen demand and total ammonia nitrogen emission has also increased (Chen et al., 2019; Yuan and Xiang, 2017). Wu et al. (2020) set capital, labor, and energy consumption as inputs, the actual GDP of each region as desirable output, and the industrial wastewater discharge, industrial waste gas discharge, and industrial solid waste discharge as undesirable outputs so as to examine the green development efficiency of China's provinces. Based on the same input and output variables, Jin et al. (2019) measured the green development efficiency of Chinese cities.

\subsection{Manufacturing agglomeration and total factor productivity}

Research on the impact of manufacturing agglomeration on total factor productivity is closely related to the research object of this article. It can be seen from the existing research that scholars have disagreements on the relationship between the two, which can be roughly divided into three views (Table 1):

First, manufacturing agglomeration can help to promote total factor productivity. Beeson (1987) and Ciccone (2002) used instrumental variable method to analyze the US and European samples and found that manufacturing agglomeration can significantly promote the rate of total factor productivity. Based on the dynamic panel regression method, Brülhart and Mathys (2008) and $\mathrm{Hu}$ et al. (2015) have obtained similar results. Graham (2009) has reached consistent conclusions based on panel data from 27 industries in the UK. What's more, by using the structural model to analyze the panel data of 250,000 micro-enterprises in the Netherlands, Graham (2009) also found that manufacturing agglomeration is conducive to the improvement of total factor production efficiency.

Second, manufacturing agglomeration may inhibit the increase of total factor productivity. Gopinath et al. (2004) analyzed the panel data of 246 four-digit manufacturing enterprises and found that manufacturing agglomeration may hinder the improvement of total factor productivity. Similar conclusion was also gained from the Dutch city samples (Broersma and Oosterhaven, 2009).

Third, there might be a nonlinear relationship between manufacturing agglomeration and total factor productivity. On the basis of the panel data of Chinese textile companies, Lin et al. (2011) found that there is a significant inverted " $U$ " relationship between industrial agglomeration and total factor productivity, that is, when industrial agglomeration is lower than the critical value, industrial agglomeration can help to promote total factor productivity; when industrial agglomeration exceeds the critical value, however, industrial agglomeration would hinder the increase of total factor productivity. 
180 Research on the Relationship between Manufacturing Agglomeration and Total Factor Productivity

\begin{tabular}{|c|c|c|c|c|c|c|c|c|}
\hline Author & Year & Sample & Method & Conclusion & $\begin{array}{c}\text { Instrumental } \\
\text { Variable }\end{array}$ & $\begin{array}{c}\text { Transmission } \\
\text { Mechanism }\end{array}$ & $\begin{array}{c}\text { Spatial } \\
\text { Spillover Effect }\end{array}$ & $\begin{array}{c}\text { Efficiency } \\
\text { Decomposition }\end{array}$ \\
\hline Beeson (1987) & $1959-1973$ & 48 States in the US & $\begin{array}{c}\text { Two Stage Least } \\
\text { Square }\end{array}$ & Promote & Test & Not Test & Not Test & Test \\
\hline Ciccone (2002) & $\begin{array}{c}\text { 1986、 } \\
\text { 1987、1988 }\end{array}$ & 5 European countries & $\begin{array}{c}\text { Two Stage Least } \\
\text { Square }\end{array}$ & Promote & Test & Not Test & Not Test & Not Test \\
\hline Graham (2007) & $1995-2002$ & 27 industries in the UK & Crossover model & Promote & Not Test & Not Test & Not Test & Not Test \\
\hline $\begin{array}{c}\text { Brülhart \& Mathys } \\
\text { (2008) }\end{array}$ & $1980-2003$ & 171 regions in Europe & $\begin{array}{c}\text { Dynamic panel } \\
\text { model }\end{array}$ & Promote & Test & Not Test & Not Test & Not Test \\
\hline $\begin{array}{l}\text { Rizov et al. } \\
\text { (2012) }\end{array}$ & $1997-2006$ & 250,000 Dutch enterprises & Structural model & Promote & Not Test & Not Test & Not Test & Test \\
\hline Hu et al. (2015) & $2000-2007$ & Chinese enterprises & Panel data model & Promote & Not Test & Not Test & Not Test & Not Test \\
\hline $\begin{array}{l}\text { Gopinath et al. } \\
\text { (2004) }\end{array}$ & $1985-1996$ & $\begin{array}{l}\text { 4-digit manufacturing } \\
\text { companies in the US }\end{array}$ & Panel data model & Hinder & Not Test & Not Test & Not Test & Not Test \\
\hline Broersma（2009） & $1991-2001$ & 40 Dutch cities & Panel data model & Hinder & Not Test & Not Test & Not Test & Not Test \\
\hline Lin et al. (2011) & $2000-2005$ & Chinese textile companies & Panel data model & Nonlinear & Not Test & Not Test & Not Test & Not Test \\
\hline
\end{tabular}


In summary, although extensive research has been done on the relationship between manufacturing agglomeration and total factor productivity, there are still some shortcomings. First, most of the studies only examine the impact of manufacturing agglomeration on economic development, whereas few have considered the comprehensive impact of manufacturing agglomeration on economic development and environmental pollution. Second, existing research seems to have relatively homogenous measurement of the input and output of green development efficiency, without concerning diverse features of green development efficiency in the new era. Third, there might be serious endogenous problems between manufacturing agglomeration and economic development or environmental pollution, yet little literature has delved into this problem.

\section{Conception framework}

Although Marshall (1920) first revealed the mechanism of manufacturing agglomeration from the effects of labor pool, intermediate input sharing, and knowledge and technology spillover, Duranton and Puga (2004) believe that Marshall only explores the micro-mechanism of agglomeration economy from the perspective of matching input factors of the enterprises. They systematically reveal the micro-mechanism of agglomeration economy from three dimensions, including sharing, matching, and learning. Therefore, this article tries to analyze how manufacturing agglomeration affects green development efficiency from these three mechanisms: sharing, matching, and learning.

\subsection{Sharing}

Through sharing mechanism, manufacturing agglomeration would affect green development efficiency by increasing returns to scale, sharing diversification, specialization profit, and joint risk prevention. (1) Increasing returns to scale. Large amounts of fixed construction costs are required to build infrastructure, and the marginal costs of consumers using these public goods are fixed. Only by ensuring maximum improvement of the commuting situation between consumers and quasipublic goods can the optimal allocation of public product resources be achieved. By virtue of the spatial proximity (Raiher, 2019), the enterprises in the cluster can share indivisible public goods and facilities, which might reduce their marginal production costs. However, the expansion of production scales in the cluster might also increase the total energy consumption, thus reduces the 
efficiency level of regional green development. (2) Sharing diversification and specialization profit.

211 Under the background of complete market competition and constant returns to scale, comparative

212 advantages in production and increasing returns to scale can be gained through diversified 213 agglomeration (Duranton and Puga, 2004). The diversified and specialized manufacturing agglomeration can not only meet various consumer needs, but also stimulate the enterprises' innovation through differentiated competition (Zeng et al., 2021). However, agglomeration of many enterprises in the same region might cause a sharp increase in factor needs and factor costs, which will increase the production costs of enterprises and reduce the efficiency level of regional green development (Brakman et al., 1996; Henderson, 2003). (3) Joint risk prevention. Through specialized and diversified agglomeration, enterprises can obtain specialized and diversified profits as well. The close connection between enterprises and the nesting of industrial chains are conducive to reducing the operational risk of individual enterprises (Overman and Puga, 2010). However, deepening cooperation between enterprises may result in further agglomeration of social resources and an increase energy consumption, thereby inhibiting regional green development.

\subsection{Matching}

Manufacturing agglomeration can affect green development efficiency by increasing matching industry is a labor-intensive industry, thus a large number of labor forces are gathered in the cluster, which increases the opportunity for employers to meet the employees and thereby compresses the temporal and spatial costs for labor recruitment for enterprises (Berliant et al., 2006). Although the increase in matching opportunities guarantees sufficient labor for the production of enterprises, it also imposes more pressure on the environment. (2) Increasing matching quality. The agglomeration of manufacturing enterprises would not only gather large population, but also attract a large number of skilled talents (Chen et al., 2020). This not only ensures the basic recruitment demands of the enterprises and reduces the cost of employment, but also meets the recruitment needs for special positions and improves the quality of matching between enterprise and employees. (3) 
Alleviating the "lock-in" dilemma. The population agglomeration brought about by industrial agglomeration can significantly alleviate the problem of "lock-in" between enterprises and employees. The "lock-in" issue results from incompleteness of contract and specific investment. It can be alleviated by agglomeration, which helps companies and employees to change partners at lower or even zero cost and accumulate funds. It should be noted that after manufacturing agglomeration improves the matching opportunities and matching quality between enterprises and labor, and alleviates the "lock-in" dilemma, the production efficiency of enterprises may be greatly improved. However, this improvement may be achieved at the cost of increased resources and energy consumption.

\subsection{Learning}

Manufacturing agglomeration can affect green development efficiency through knowledge generation, knowledge diffusion and knowledge application. Organizational learning theory holds that an enterprise is a knowledge system composed of different knowledge. Acquiring and creating knowledge through organizational learning is the source of an enterprise's competitive advantage (Grant, 1996). (1) Knowledge generation. Frequent contacts and exchanges between different enterprises and technicians in the cluster can stimulate innovative thinking and improve innovation capabilities, and thus generate new knowledge. This would in turn affect the production and environmental protection behavior of the enterprises. (2) Knowledge diffusion. With the advantage of geographical proximity, enterprises in the cluster can quickly disseminate new technologies and new products through technical exchanges and cooperation. The rapid diffusion of knowledge can guide the enterprises in the cluster to learn and re-create. (3) Knowledge application. Innovation is the source of sustaining the vitality of enterprises. The generation and diffusion of knowledge provides a suitable environment for imitation and learning of enterprises in the cluster. In the market environment of survival of the fittest, enterprises in the cluster tend to learn and innovate quickly. The production and application of a large number of innovative outcomes will help improve the efficiency level of regional green development. However, large-scale agglomeration of enterprises within a limited region can easily lead to vicious competition among enterprises, which might shrink 
the margins of individual enterprises. In this sense, funds available for $R \& D$ would be reduced, thereby reducing the probability of successful innovation, which is not conducive to regional green development (Li et al., 2021).

To sum up, manufacturing agglomeration may have either economic or uneconomical agglomeration effect on green development efficiency. If the economic agglomeration effect is greater than the uneconomic agglomeration effect, manufacturing agglomeration is conducive to improving green development efficiency, and vice versa. Therefore, rigorous measures needs to be utilized to investigate the impact of manufacturing agglomeration on green development efficiency.

\section{Research Design}

\subsection{Econometric models}

Based on theoretical analysis, this paper establishes the following benchmark measurement model:

$$
\ln G D E_{i t}=a_{1}+\beta_{1} \ln M A_{-} L Q_{i t}+\gamma_{j} \sum \ln X_{i t}+u_{i}+v_{t}+\varepsilon_{i t}
$$

Among them, $G D E_{i t}$ represents the green development efficiency in the $t$ period of $i$ region; $M A_{-} L Q_{i t}$ represents the manufacturing agglomeration degree in the $t$ period of $i$ region; $X_{i t}$ is a series of control variables; $\beta_{1}$ and $\gamma_{j}$ are explanatory variables and the parameters of the control variables; $u_{i} 、 v_{t}$ represent individual fixed effects and temporal fixed effects respectively, and $\varepsilon_{i t}$ is a random interference term.

This article decomposes green development efficiency into green development technology efficiency (GDTC) and green development technology progress (GDTP). Examining the impact of manufacturing agglomeration on components of green development efficiency can provide an indepth analysis of the complex mechanism between the two. The equations are:

$$
\begin{aligned}
& \operatorname{lnGDTC}_{i t}=a_{2}+\beta_{2} \ln M A_{-} L Q_{i t}+\theta_{j} \sum \ln X_{i t}+\iota_{i}+\kappa_{t}+\epsilon_{i t} \\
& \operatorname{lnGDTP} P_{i t}=a_{3}+\beta_{3} \ln M A_{-} L Q_{i t}+\delta_{j} \sum \ln X_{i t}+\lambda_{i}+\varpi_{t}+\zeta_{i t}
\end{aligned}
$$

This paper further expands equation (4) spatially, by including the spatial lagged terms of manufacturing agglomeration and green development efficiency in the model to control its spatial 
correlation, and investigating the relationship between the two based on the Spatial Panel Durbin Model (SPDM) (Song et al., 2020; Zhang et al., 2020). It is expressed as follows:

$$
\begin{aligned}
\ln G D E_{i t}=a_{4} & +\rho \sum_{i=1}^{n} W_{i t} \ln G D E_{i t}+\phi_{1} \ln M A_{-} L Q_{i t}+\tau_{1} \sum_{i=1}^{n} W_{i t} \ln M A_{-} L Q_{i t} \\
& +\vartheta_{j} \sum_{i=1}^{n} \ln X_{i t}+\tau_{j} \sum_{i=1}^{n} W_{i t} \ln X_{i t}+\varrho_{i}+\varphi_{t}+\xi_{i t}
\end{aligned}
$$

$$
\text { Among them, } W_{i t} \text { is the spatial weight matrix; } \phi_{1} \text { and } \vartheta_{j} \text { are the parameter to be estimated }
$$

for each explanatory variable and control variable; $\rho$ is the spatial lag coefficient of the dependent variable; $\tau_{1}$ and $\tau_{j}$ are the spatial lag coefficient for each explanatory variable and the control variable; $\varrho_{i}$ and $\varphi_{t}$ represent individual fixed effects and temporal fixed effects respectively, and $\xi_{i t}$ is the random interference term.

Since traditional point estimation methods cannot truly measure the impact of explanatory variables on the explained variables (Guliyev, 2020), some scholars have proposed partial differential decomposition (He et al., 2020; Lu et al., 2021). Therefore, this paper mainly analyzes the impact of manufacturing agglomeration on green development efficiency based on the results of partial differential decomposition.

The spatial weight matrix is the core element of spatial econometric analysis (Kopczewska et al., 2017). With the development of modern economy and society, the factors that affect spatial correlation between variables are no longer limited to geographical distance, yet economic development level, information technology and other factors have become increasingly important. Therefore, this paper intends to construct an asymmetric spatial weight matrix $\left(\mathrm{W}_{1}\right)$ that considers both geographic distance and economic development level to quantify the spatial correlation between manufacturing agglomeration and green development efficiency (Yuan et al., 2020). The equations are as follows:

$$
\begin{gathered}
W_{1}=W_{d} \times \operatorname{diag}\left(\bar{Y}_{1} / \bar{Y}, \bar{Y}_{2} / \bar{Y}, \cdots, \bar{Y}_{n} / \bar{Y}\right) \\
\bar{Y}_{l}=\sum_{t_{0}}^{t_{1}} Y_{i t} /\left(t_{1}-t_{0}+1\right), \bar{Y}=\sum_{i=1}^{n} \sum_{t_{0}}^{t_{1}} Y_{i t} / n\left(t_{1}-t_{0}+1\right)
\end{gathered}
$$


Among them, $W_{d}$ is the geographic distance weight matrix; $\bar{Y}_{\iota}$ is the average per capita GDP

314 in the period between $t_{0}$ and $t_{1}$ of city $i ; \bar{Y}$ is the average per capita GDP of all cities in the

315 research period. Two different economic distance matrices, $\mathrm{W}_{2}$ (Feng et al., 2019) and $\mathrm{W}_{3}$ (Wang

316 and He, 2019), were used as substitutes for the robustness test.

317 New economic geography believes that manufacturing agglomeration is endogenous to

318 economic growth, which has significant endogenous problems itself (Yuan et al., 2020). Since

319 regions with high green development efficiency are generally underdeveloped cities, to obtain

320 political promotion, local officials usually lower the threshold of environmental regulations to

321 attract enterprises to settle down, thereby promoting the local manufacturing agglomeration (Miao

322 et al., 2019a). To this end, this paper selects the treaty ports opened in Qing Dynasty from 1842 to

3231909 as the instrumental variable of manufacturing agglomeration to alleviate the estimation bias

324 caused by indigenousness (Chen et al., 2018a). Besides, to ensure that the instrument variables can

325 change with time in the panel data analysis, this paper multiplies the instrument variable with the

326 year dummy variable (Nunn and Qian, 2014).

327 The trade ports opened in the Qing Dynasty from 1842 to 1909 are selected as the instrumental 328 variable of the endogenous variable for reasons as follows. (1) To meet the requirements of 329 relevance. The trade ports forced to open in the Qing Dynasty from 1842 to 1909 were important 330 industrial and commercial cities in modern China. Because of convenient transportation, these cities 331 become clusters of population and overseas investment. They are also the most developed areas of 332 modern business culture in China, which have an important influence on the formation of 333 manufacturing agglomeration (Chen et al., 2018b). (2) Meet the exogenous requirements. The trade 334 ports opened in the Qing Dynasty from 1842 to 1909 have a history of more than a hundred years, 335 so they will not affect current green development efficiency.

\section{4.2. Variable description}

\subsubsection{Explained variable}

This paper uses the Super slack-based measure model (SBM) to measure Green Development Efficiency in the YREB (Long et al., 2020). The super SBM model aims to maximize desirable output such as GDP considering the productive factors including labor and capital and minimize

341 undesirable output such as industrial sulfur dioxide emissions (Tone, 2002). The formula is as 342 follows: 


$$
\operatorname{Min} G D E^{*}=\frac{\frac{1}{m} \sum_{i=1}^{m} s_{i}^{-} / c_{i k}}{\frac{1}{q_{1}+q_{2}}\left(\sum_{r=1}^{q_{1}} \frac{s_{r}^{g+}}{y_{r k}}+\sum_{t=1}^{q_{2}} \frac{c}{y_{t k}}\right)}
$$

$$
\text { s.t. }\left\{\begin{array}{c}
s_{i}^{-} \geq \sum_{j=1, j \neq k}^{n} x_{i j} \lambda_{j}, i=1, \cdots, m ; \\
s_{r}^{g+} \leq \sum_{j=1, j \neq k}^{n} y_{r j}^{g} \lambda_{j}, r=1, \cdots, q_{1} ; \\
s_{r}^{g+} \geq \sum_{j=1, j \neq k}^{n} y_{t j}^{b} \lambda_{j}, t=1, \cdots, q_{2} ; \\
\lambda_{j} \geq 0, j=1, \cdots, n, j \neq 0 \\
s_{i}^{-} \geq x_{i k}, i=1, \cdots, m ; s_{r}^{g+} \leq y_{r k}, r=1, \cdots, q_{1} ; s_{t}^{b-} \geq y_{t k}, t=1, \cdots, q_{2} ;
\end{array}\right.
$$

Where $G D E^{*}$ represents the value of green development efficiency; $x$ is the input vector; $n$

346 is the number of decision-making units; $m$ is the number of input factors; $q_{1}, q_{2}$ represent the

347 desirable output and undesirable output, respectively; $s_{i}^{-}, s_{r}^{g+}, s_{t}^{b-}$ represent the slack vectors of input desirable output and undesirable output, respectively. $G D E^{*}>0$, the larger the value of $G D E^{*}$,

349 the higher the green development efficiency. Concerning the richness and complexity of the connotation of green development, this article refers to Liang et al. (2019) and selects multi-input and multi-output variables to calculate green development efficiency (Table 2).

\section{Table 2}

\begin{tabular}{|c|c|c|c|}
\hline \multicolumn{4}{|c|}{ Types of indicators } \\
\hline & First-level indicator & Second-level indicator & Unit \\
\hline \multirow{6}{*}{ Input } & Labor input & $\begin{array}{c}\text { Number of employees at the end of the year per } \\
\text { unit }\end{array}$ & $\begin{array}{l}10 \text { thousand } \\
\text { people }\end{array}$ \\
\hline & Capital input & $\begin{array}{l}\text { The actual fixed assets investment of the whole } \\
\text { society }\end{array}$ & $\begin{array}{l}10 \text { thousand } \\
\text { Yuan }\end{array}$ \\
\hline & Energy input & Electricity consumption of the whole society & $\begin{array}{l}10 \text { thousand } \\
\mathrm{kW} \cdot \mathrm{h}\end{array}$ \\
\hline & \multirow{3}{*}{ Resource input } & Urban built-up area & $\mathrm{km}^{2}$ \\
\hline & & Urban road area per capita & $\mathrm{m}^{2} /$ person \\
\hline & & Total urban water supply & 10 thousand $\mathrm{m}^{3}$ \\
\hline \multirow{5}{*}{ Desirable output } & Economic output & Real GDP & $\begin{array}{l}10 \text { thousand } \\
\text { Yuan }\end{array}$ \\
\hline & Technical output & Number of patents granted at the end of the year & Item \\
\hline & & Green area of city park & Hectare \\
\hline & Ecological output & Urban green area & Hectare \\
\hline & & Green coverage area in built-up area & Hectare \\
\hline \multirow{2}{*}{$\begin{array}{l}\text { Undesirable } \\
\text { output }\end{array}$} & \multirow{2}{*}{$\begin{array}{l}\text { Three kinds of industrial } \\
\text { waste }\end{array}$} & Industrial sulfur dioxide & Ton \\
\hline & & $\begin{array}{l}\text { Industrial wastewater discharge } \\
\text { Industrial soot (dust) emissions }\end{array}$ & $\begin{array}{l}\text { Ten thousand ton } \\
\text { Ton }\end{array}$ \\
\hline
\end{tabular}

353 Input-output indicators of green development efficiency 


\subsubsection{Core explanatory variable}

Manufacturing agglomeration is the core explanatory variable of this article. This study mainly uses location entropy index to describe the urban manufacturing agglomeration levels because location entropy model can better eliminate the endogenous impact brought by regional scale differences, and can more accurately describe the distribution of China's urban manufacturing agglomeration (Qu et al., 2020). The formula is as follows:

$$
M A_{-} L Q_{i t}=\frac{c e m_{i t} / N E M_{i t}}{\sum c e m_{t} / \sum N E M_{t}}
$$

Where $M A_{-} L Q_{i t}$ represents the degree of manufacturing agglomeration in city $i$ in year $t$; $c e m_{i t}$ represents the employment in manufacturing in city $i$ in year $t ; N E M_{i t}$ represents the total employment in city $i$ in year $t ; \sum \mathrm{cem}_{t}$ represents the total employment in manufacturing in all cities in year $t ; \sum N E M_{t}$ represents the total employment in all cities in year $t$.

\subsubsection{Control variables}

New Economic Growth Theory (NEG) holds that economic growth is affected not only by physical capital, but also by human capital (HC). HC can often affect economic growth and environmental quality through promoting technological progress and environmental awareness (Balaguer and Cantavella, 2018). Therefore, this article uses the average years of education to measure human capital.

The industrial sector is the largest source of pollutant emissions (Shao et al., 2011), so rapid industrialization might lead to a sharp increase in energy consumption, which would intensify pollutant emissions (Lv et al., 2020). Therefore, this paper uses the proportion of added value of the secondary industry to GDP to describe the industrialization level (IND).

Coal consumption accounts for more than half of China's total energy consumption and contributes $1 / 3$ of $\mathrm{CO}_{2}$. This consumption structure that relies heavily on fossil energy may have a critical impact on China's economic transformation and environmental governance (Wei et al., 2020). Therefore, this paper uses the ratio of industrial electricity consumption to electricity consumption of the whole society to describe the impact of energy consumption structure (EC) on green development efficiency. 
Environmental regulation (ER) would increase the production cost of enterprises and induce fluctuations in the total factor productivity of manufacturing enterprises (Yu and Wang, 2021). To reduce economic losses, the government is likely to consciously lower the threshold of environmental regulation, which can easily lead to "racing at the bottom" between regions (Miao et al., 2019b). Therefore, this article uses the environmental regulation index to describe the intensity of environmental regulation (Miao et al., 2019b).

Technological innovations (TI) are not only important drivers of economic growth, but also an important way of environmental protection (Miao et al., 2019b). Therefore, this paper uses the logarithm of the number of patent grants obtained per 10,000 people to measure and introduces a model to control it.

The increase in population density (PD) would not only cause an increase in resource and energy demand, but also cause further environmental damage due to unreasonable development methods. Therefore, this paper uses the ratio of the total urban population at the end of the year to the area of the administrative region to measure population density (Qiu et al., 2019).

\subsection{Study area}

In September 2014, the State Council clarified the geographic scope of the YREB in the Guiding Opinions on Relying on the Golden Waterway to Promote the Development of the YREB, which covers 11 provinces and cities including Shanghai, Jiangsu, Zhejiang, Anhui, Jiangxi, Hubei, Hunan, Chongqing, Sichuan, Yunnan, and Guizhou, with an area of about 2.05 million square kilometers, and the population and GDP of more than $40 \%$ of the whole China. The YREB is considered as the most potential growth area in the new era and as important as half of the country. 


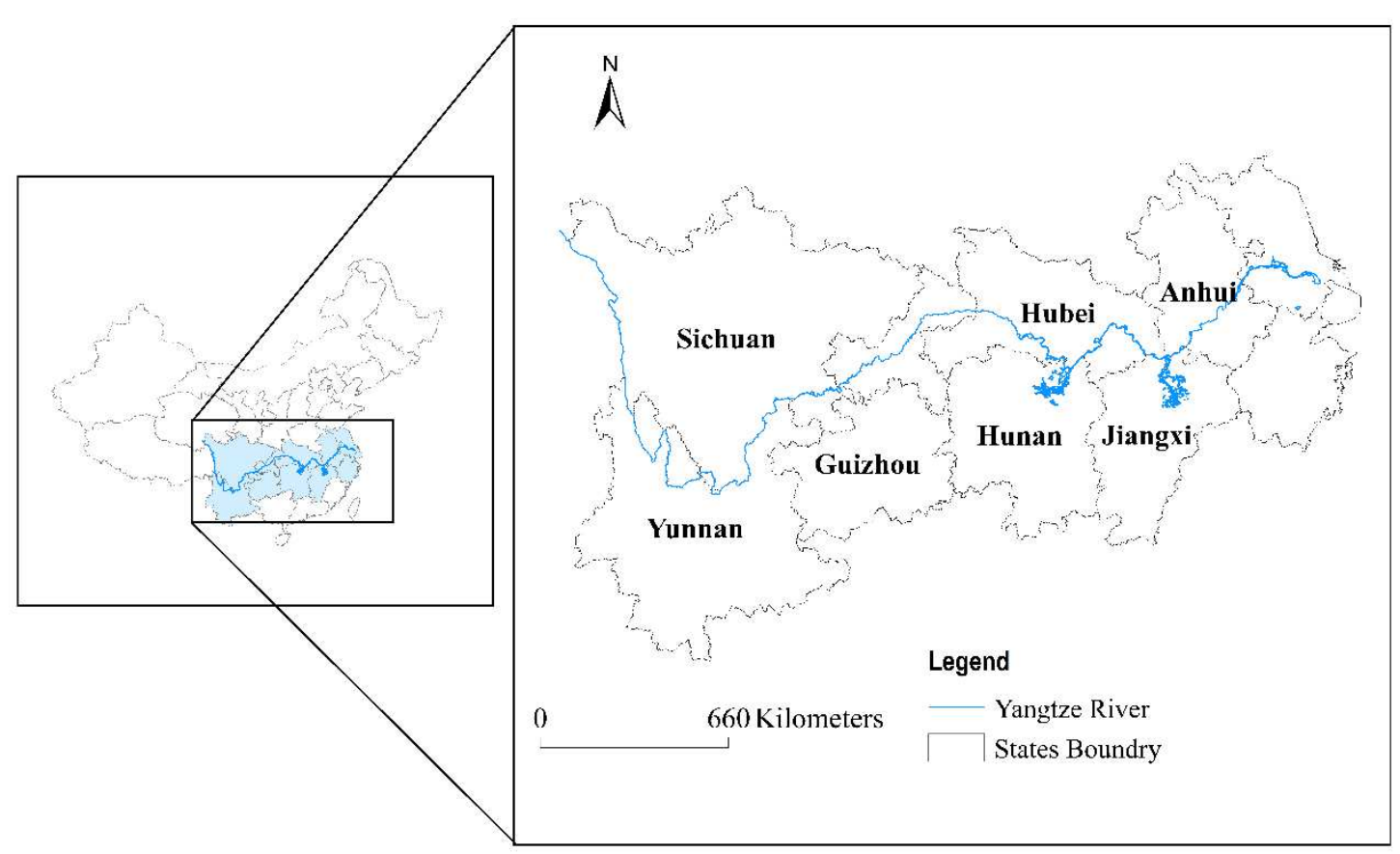

Fig. 1. The geographical scope of the YREB

\subsection{Data source and description}

The sample in this article is the panel data of 110 cities in the YREB from 2003 to 2016, in which the economic variables are collected from China City Statistical Yearbook and the meteorological factors from the China Meteorological Data Center (http://data.cma.cn/). Due to the statistical errors, this article supplements and adjusts the individual missing data and outliers in the data set using interpolation. To eliminate the impact of inflation, with Year 2003 as the base period, the GDP deflator index method is used to adjust all price variables. The Boxplot of the variables is shown in Fig. 2.

According to Fig. 2, MA_LQ and IND basically conform to the normal distribution, and there is no serious outlier. However, the mean values of GDE, HC, ES, TI, and PD are significantly larger than their medians. The data are mainly concentrated in low-value intervals and have obvious positive skewness. In addition, the mean value of the two variables ES and ER is smaller than their medians, and the data distribution has obvious heavy tail and negative skewness. Therefore, to reduce the possible effect of heteroscedasticity, this paper performs logarithmization on each variable. 

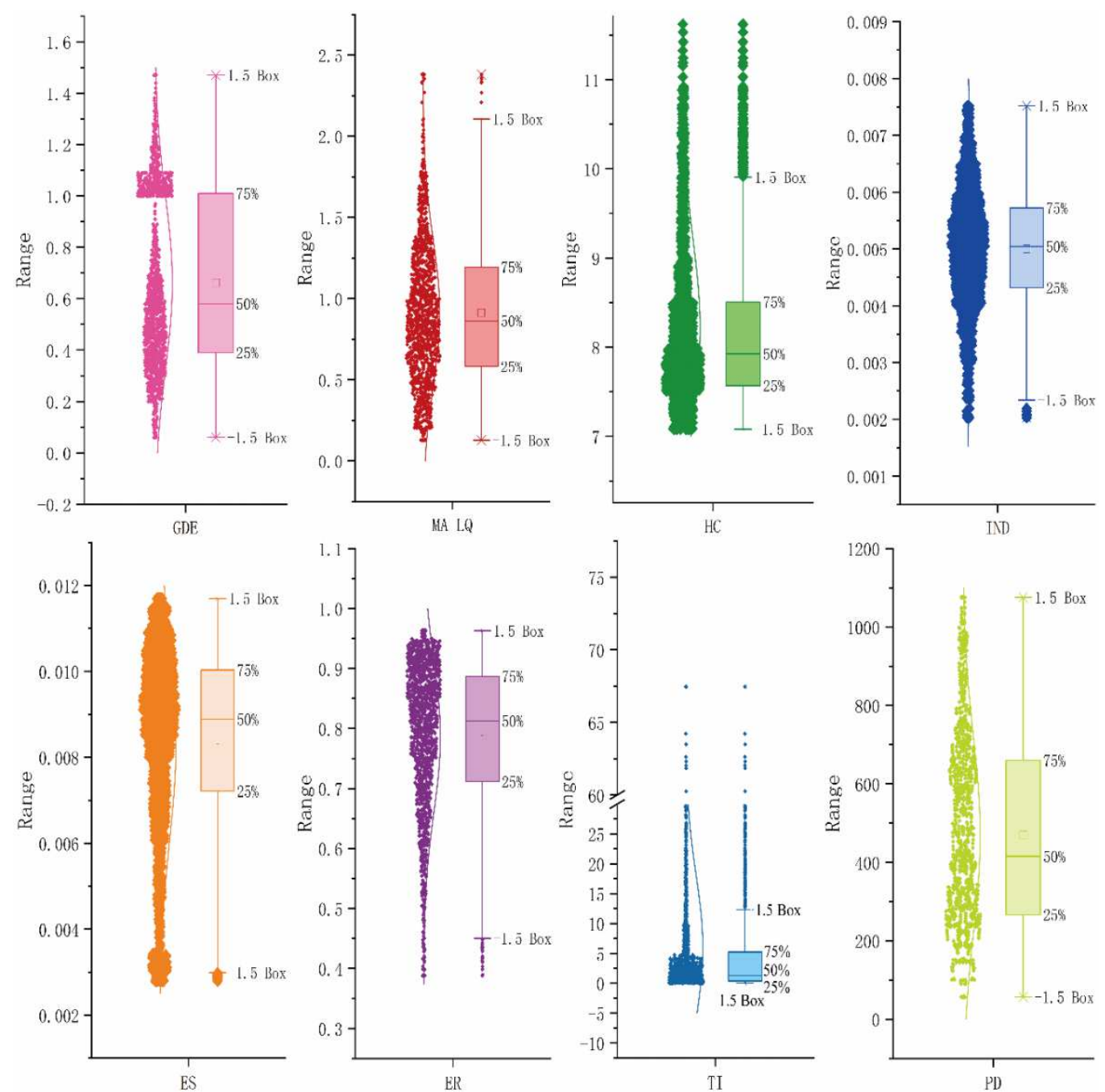

Fig. 2. Boxplot of variables

To avoid the deviation of the regression results due to the collinearity between variables, this paper uses multiple collinearity test and correlation coefficient test to analyze the main variables. According to the multicollinearity test results in Table 3, the minimum value of VIF is 1.19 and the maximum value is 2.68 , both of which are lower than the critical value of 10 , which indicates that there is no serious collinearity problem between explanatory variables. Besides, the correlation coefficient test further confirms that the maximum correlation coefficient value between the explanatory variables is 0.5972 and the minimum value is -0.0044 , and the correlation coefficient between most variables has passed the significance test at the level of $10 \%$. This shows that there are no serious highly correlated or uncorrelated problems among the explanatory variables. Therefore, the multicollinearity problem can be ignored in the regression analysis later. 
433 Multicollinearity test and correlation coefficients between variables.

\begin{tabular}{|c|c|c|c|c|c|c|c|c|c|}
\hline & VIF & $\operatorname{lnGDE}$ & lnMA_LQ & $\ln \mathrm{HC}$ & $\operatorname{lnIND}$ & $\ln E S$ & $\operatorname{lnER}$ & $\operatorname{lnTI}$ & $\ln P D$ \\
\hline $\operatorname{lnGDE}$ & - & 1 & & & & & & & \\
\hline lnMA_LQ & 1.91 & $0.0837 *$ & 1 & & & & & & \\
\hline $\operatorname{lnHC}$ & 1.57 & $0.1297 *$ & $0.3579 *$ & 1 & & & & & \\
\hline $\operatorname{lnIND}$ & 1.45 & $0.1226^{*}$ & $0.4901 *$ & $0.1532 *$ & 1 & & & & \\
\hline $\ln E S$ & 1.19 & -0.0044 & $0.2377 *$ & 0.0281 & $0.3194 *$ & 1 & & & \\
\hline $\operatorname{lnER}$ & 1.60 & $0.2613 *$ & $0.3301 *$ & $0.3432 *$ & $0.2328^{*}$ & -0.0291 & 1 & & \\
\hline $\ln \mathrm{TI}$ & 2.68 & $0.2841 *$ & $0.5738 *$ & $0.5814^{*}$ & $0.2654^{*}$ & -0.0347 & $0.5972 *$ & 1 & \\
\hline $\ln \mathrm{PD}$ & 1.32 & $0.2186^{*}$ & $0.3111 *$ & $0.3735^{*}$ & $0.2879 *$ & $0.1153 *$ & $0.3404 *$ & $0.4105 *$ & 1 \\
\hline
\end{tabular}

\section{Empirical results}

\subsection{Analysis of the imbalance of green development efficiency}

The YREB traverses the West, Middle and East China. Since their internal natural conditions and economic development levels are quite different, the green development efficiency of each region tends to be distinct. According to the standards of the "Guiding Opinions of the State Council on Promoting the Development of the YREB Relying on Golden Waterways", this article defines the upper reaches of the YREB as 33 cities in 4 provinces of Yunnan, Guizhou, Sichuan and

442 Chongqing, the middle reaches as 36 cities in 3 provinces of Hubei, Hunan and Jiangxi, and lower reaches as 41 cities in 4 provinces of Jiangsu, Zhejiang, Shanghai, and Anhui. Besides, the Theil index and its decomposition method are used to measure the overall and internal gaps in green development efficiency of the YREB. The Theil index was first used to measure income inequality between regions (Theil and Uribe, 1967). This method has good decomposition qualities, so it is often used to analyze regional differences and the sources of these differences.

\subsubsection{The overall gap in green development efficiency}

It can be seen from Fig. 3 and Table 4 that the overall gap in green development efficiency across the YREB is huge, and there is a tendency of further expansion. The driving force behind this expansion tendency mainly comes from intra-regional differences, with an average annual 
contribution of $96.80 \%$, while the inter-regional differences are rather small. During the sample

453 period, the evolution of the overall gap in green development efficiency of the YREB can be roughly

454 divided into four stages. It falls from the beginning of 2004-2005 to a historically low level of 0.101

455 in the first stage; the second stage of 2005-2006 is a stagnation period; the third stage is a period of

456 sharp fluctuation, rising from 0.108 in 2006 to 0.5066 in 2015 with an increase of nearly 5 times;

457 and in the fourth stage, there is a slow downward trend from 2015 onwards.

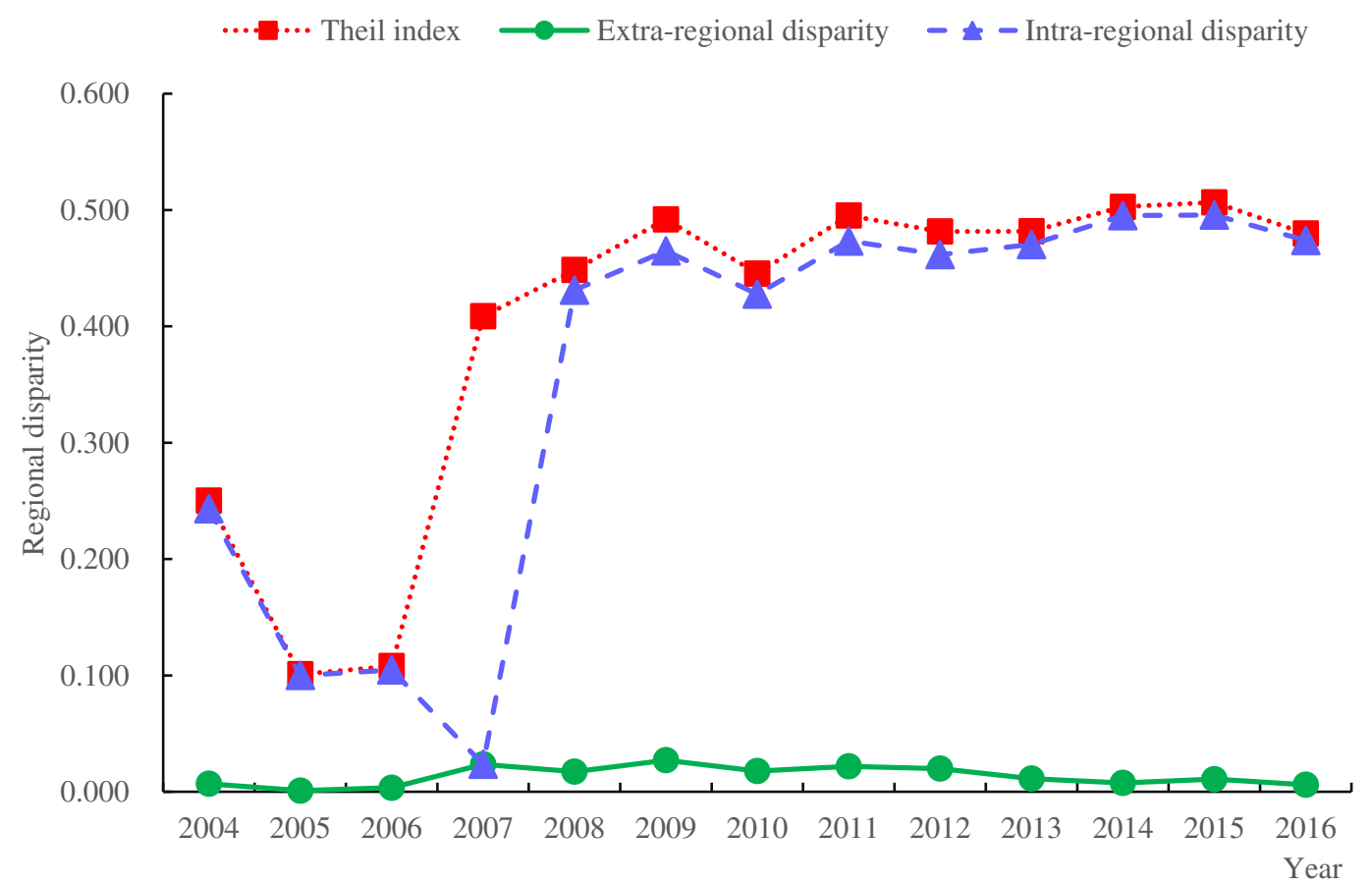

Fig. 3. Overall gap and decomposition of green development efficiency in the YREB. 
463 The Theil index of green development efficiency of the YREB and its decomposition contribution rate

\begin{tabular}{|c|c|c|c|c|c|c|c|c|c|c|c|c|c|}
\hline Index & 2004 & 2005 & 2006 & 2007 & 2008 & 2009 & 2010 & 2011 & 2012 & 2013 & 2014 & 2015 & 2016 \\
\hline Theil index & 0.250 & 0.101 & 0.108 & 0.409 & 0.449 & 0.492 & 0.445 & 0.495 & 0.482 & 0.482 & 0.503 & 0.507 & 0.480 \\
\hline Regional gap & 0.007 & 0.001 & 0.004 & 0.024 & 0.017 & 0.027 & 0.018 & 0.022 & 0.020 & 0.011 & 0.008 & 0.011 & 0.006 \\
\hline Interregional contribution $/ \%$ & 2.780 & 0.960 & 3.200 & 5.770 & 3.870 & 5.510 & 3.990 & 4.420 & 4.130 & 2.340 & 1.510 & 2.150 & 1.250 \\
\hline Intraregional gap & 0.243 & 0.100 & 0.105 & 0.024 & 0.431 & 0.465 & 0.428 & 0.473 & 0.462 & 0.470 & 0.495 & 0.496 & 0.474 \\
\hline Intraregional contribution $/ \%$ & 97.220 & 99.040 & 96.800 & 94.230 & 96.130 & 94.490 & 96.010 & 95.580 & 95.870 & 97.660 & 98.490 & 97.850 & 98.750 \\
\hline Gap of lower reaches & 0.074 & 0.090 & 0.101 & 0.181 & 0.207 & 0.171 & 0.296 & 0.344 & 0.316 & 0.225 & 0.178 & 0.260 & 0.195 \\
\hline Contribution of lower reaches $/ \%$ & 9.980 & 35.140 & 38.280 & 16.300 & 17.810 & 13.750 & 29.240 & 32.480 & 29.490 & 20.170 & 13.090 & 19.020 & 14.560 \\
\hline Gap of middle reaches & 0.093 & 0.111 & 0.094 & 0.092 & 0.212 & 0.160 & 0.215 & 0.359 & 0.393 & 0.638 & 0.606 & 0.565 & 0.544 \\
\hline Contribution of middle reaches $/ \%$ & 11.490 & 35.300 & 27.660 & 5.470 & 11.750 & 7.390 & 11.780 & 18.050 & 19.690 & 34.890 & 33.760 & 30.110 & 33.110 \\
\hline Gap of upper reaches & 0.535 & 0.101 & 0.124 & 0.763 & 0.818 & 0.954 & 0.776 & 0.789 & 0.726 & 0.676 & 0.741 & 0.686 & 0.703 \\
\hline Contribution of upper reaches $/ \%$ & 75.750 & 28.600 & 30.860 & 72.460 & 66.570 & 73.350 & 55.000 & 45.060 & 46.690 & 42.600 & 51.640 & 48.720 & 51.090 \\
\hline
\end{tabular}




\subsubsection{Internal gap of green development efficiency}

According to Fig. 3 and Table 4, the largest gap in green development efficiency occurs in the upper reaches of the YREB, followed by the middle and lower reaches. The annual average value of regional gap of green development efficiency is 0.646 in the upper reaches, which is much higher than that of 0.314 in the middle reaches and that of 0.203 in the lower reaches. It is almost twice the value of the middle reaches and three times of the lower reaches, indicating that green development efficiency within the YREB is extremely uneven and the green development efficiency gap in the upper reaches mainly determines the green development efficiency tendency of the entire YREB with its contribution rate as high as $52.95 \%$.

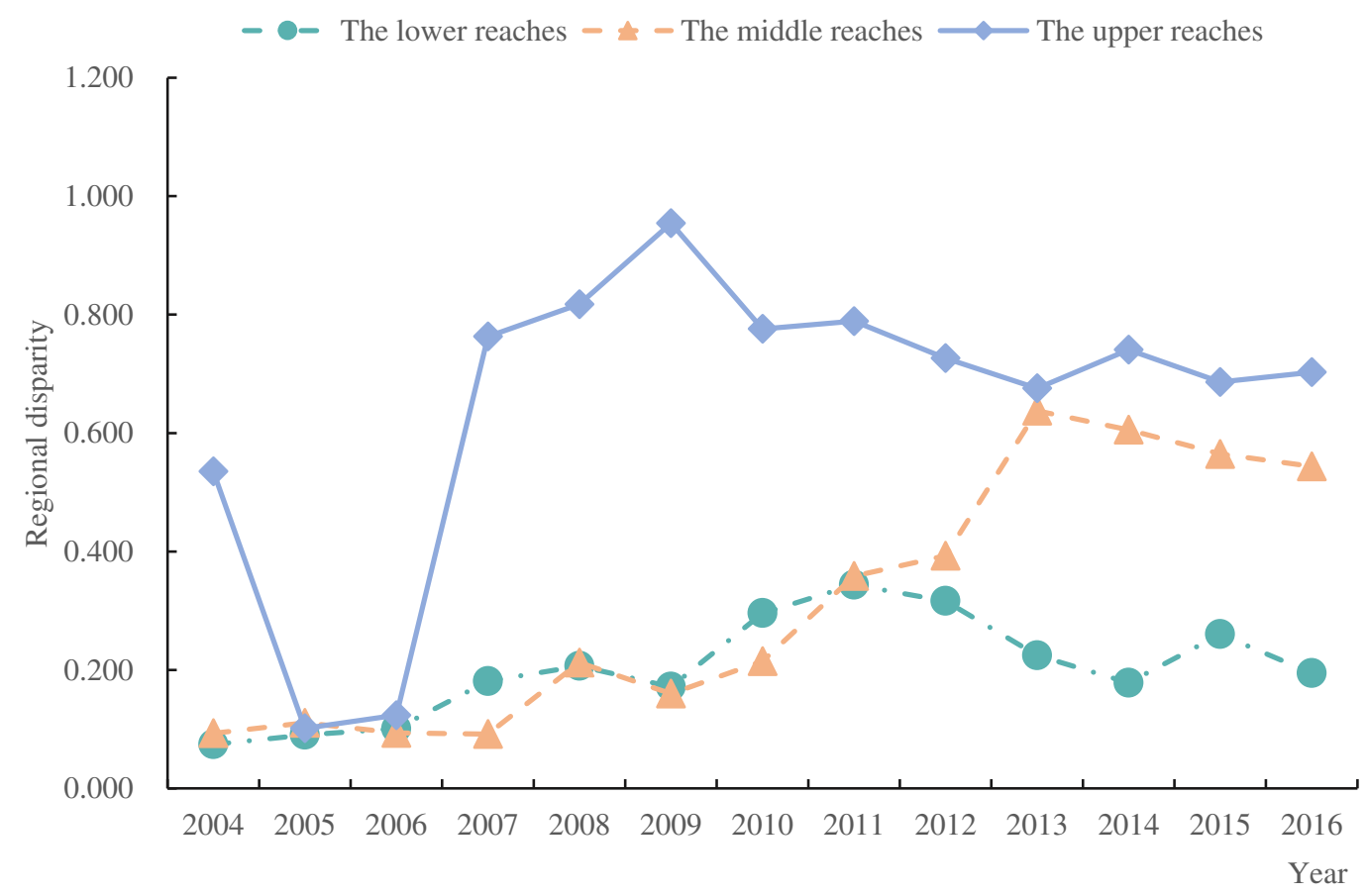

Fig. 4. Internal gap in green development efficiency of the YREB.

The three major regions present an evolution trend of "decline-rise-decline". From 2004 to 2006, the gap in the upper reaches drops from 0.535 to 0.124 ; from 2006 to 2009 , it rapidly increases to 0.954 ; and since 2009 , it gradually declines. The gap between the middle and lower reaches is basically at a low level of about 0.2 before 2011, but after 2011, the gap in the middle reaches expands rapidly, which is much higher than that of the lower reaches. At the end of 2016, the regional gap in green development efficiency in the middle reaches is as high as 0.544 , almost five 
times that of the lower reaches.

5.2. Impact of manufacturing agglomeration on green development efficiency

Before examining the impact of manufacturing agglomeration on green development efficiency, this paper has carried out correlation tests on models and instrumental variables (Table 5). First, based on the method proposed by Davidson and MacKinnon (1993), the study has tested whether the model has endogenous problems. The estimation results in the first stage show that under the control of individual fixed effects and temporal fixed effects, the Davidson-MacKinnon test rejects the hypothesis that there is no endogeneity at the confidence level of $1 \%$. Second, the significance test of the sargan test fails, indicating that the instrumental variables selected in this paper are valid. Finally, it is observed that there is a significant positive correlation between instrumental variables and manufacturing agglomeration, which basically passed the significance test at the level of $1 \%$, indicating that the instrumental variables meet the correlation hypothesis. In summary, it seems that the instrument variables selected in this paper are relatively reasonable.

496 2SLS regression results in the first stage

\begin{tabular}{|c|c|c|}
\hline Variable & Coefficient & T-value \\
\hline dum_qin $\times$ year2004 & $0.231 * * *$ & $(3.60)$ \\
\hline dum_qin $\times$ year2005 & $0.255^{* * * *}$ & $(3.62)$ \\
\hline dum_qin $\times$ year2006 & $0.231 * * *$ & $(3.27)$ \\
\hline dum_qin $\times$ year2007 & $0.252 * * *$ & $(3.57)$ \\
\hline dum_qin $\times$ year2008 & $0.283 * * *$ & $(4.02)$ \\
\hline dum_qin ×year2009 & $0.289 * * *$ & $(4.10)$ \\
\hline dum_qin $\times$ year2010 & $0.302 * * *$ & $(4.29)$ \\
\hline dum_qin×year2011 & $0.272 * * *$ & $(3.87)$ \\
\hline dum_qin $\times$ year2012 & $0.230 * * *$ & $(3.27)$ \\
\hline dum_qin $\times$ year2013 & $0.161 * *$ & $(2.28)$ \\
\hline dum_qin $\times$ year2014 & $0.128 *$ & $(1.81)$ \\
\hline dum_qin $\times$ year2015 & $0.134 *$ & $(1.90)$ \\
\hline dum_qin×year2016 & 0.111 & $(1.58)$ \\
\hline City fixed effect & \multicolumn{2}{|c|}{ Yes } \\
\hline Control variable & \multicolumn{2}{|c|}{ Yes } \\
\hline Davidson-MacKinnon test & \multicolumn{2}{|c|}{$14.517(0.000)$} \\
\hline Sargan test & \multicolumn{2}{|c|}{$13.302(0.274)$} \\
\hline Observations & \multicolumn{2}{|c|}{1430} \\
\hline $\mathrm{R}^{2}$ & \multicolumn{2}{|c|}{0.914} \\
\hline
\end{tabular}


498 investigate the relationship between manufacturing agglomeration and green development 499 efficiency. From the results in Table 6, we can see that under the estimation of the OLS, FE and 500 FGLS methods, the regression coefficients of manufacturing agglomeration are always significantly 501 negative and have passed the significance test at the levels of both $5 \%$ and $1 \%$. This shows that manufacturing agglomeration would inhibit the improvement of green development efficiency. In

503 the case of 2SLS, there is also a significant negative relationship between manufacturing

504 agglomeration and pollutant emission, which has passed the significance test at the level of 5\%.

505 This is consistent with the OLS regression results, indicating that manufacturing agglomeration is not conducive to the improvement of green development efficiency. In addition, the absolute value

507 of the estimated coefficient of 2SLS is significantly greater than the regression coefficient of OLS.

508 This shows that if the endogenous problems of manufacturing agglomeration are not controlled, the 509 regression coefficient will be biased downward, which will lead to underestimation of the inhibitory 510 effect of manufacturing agglomeration on green development efficiency.

\section{Table 6}

512 The impact of manufacturing agglomeration on green development efficiency

\begin{tabular}{|c|c|c|c|c|}
\hline \multirow{2}{*}{ Variable } & \multicolumn{4}{|c|}{ Explained variable: $\operatorname{lnGDE}$} \\
\hline & OLS & $\mathrm{FE}$ & FGLS & 2 SLS \\
\hline lnMA_LQ & $\begin{array}{c}-0.251 * * * \\
(-4.96)\end{array}$ & $\begin{array}{c}-0.159 * * \\
(-2.36)\end{array}$ & $\begin{array}{c}-0.265^{* * *} \\
(-8.76)\end{array}$ & $\begin{array}{c}-0.799 * * \\
(-2.41)\end{array}$ \\
\hline $\operatorname{lnHC}$ & $\begin{array}{c}-0.558 * * \\
(-2.30)\end{array}$ & $\begin{array}{l}0.316 \\
(0.61)\end{array}$ & $\begin{array}{c}-0.451 * * * \\
(-4.25)\end{array}$ & $\begin{array}{l}-0.262 \\
(-0.43)\end{array}$ \\
\hline $\operatorname{lnIND}$ & $\begin{array}{c}0.275^{* *} \\
(2.54)\end{array}$ & $\begin{array}{c}-1.007 * * * \\
(-7.97)\end{array}$ & $\begin{array}{c}0.360 * * * \\
(5.93)\end{array}$ & $\begin{array}{c}-0.833 * * * \\
(-5.30)\end{array}$ \\
\hline $\ln E S$ & $\begin{array}{l}0.032 \\
(0.50)\end{array}$ & $\begin{array}{l}-0.024 \\
(-0.58)\end{array}$ & $\begin{array}{c}-0.077 * * \\
(-2.31)\end{array}$ & $\begin{array}{l}-0.018 \\
(-0.41)\end{array}$ \\
\hline $\operatorname{lnER}$ & $\begin{array}{c}0.523 * * * \\
(3.58)\end{array}$ & $\begin{array}{l}0.074 \\
(0.60)\end{array}$ & $\begin{array}{c}0.414 * * * \\
(4.92)\end{array}$ & $\begin{array}{l}0.142 \\
(1.09)\end{array}$ \\
\hline $\operatorname{lnTE}$ & $\begin{array}{c}0.124 * * * \\
(7.08)\end{array}$ & $\begin{array}{c}0.244 * * * \\
(15.01)\end{array}$ & $\begin{array}{c}0.136 * * * \\
(13.91)\end{array}$ & $\begin{array}{c}0.246 * * * \\
(14.65)\end{array}$ \\
\hline $\ln \mathrm{PD}$ & $\begin{array}{c}0.160 * * * \\
(4.14)\end{array}$ & $\begin{array}{l}0.265 \\
(0.68)\end{array}$ & $\begin{array}{c}0.165 * * * \\
(6.95)\end{array}$ & $\begin{array}{l}0.719 \\
(1.55)\end{array}$ \\
\hline Constant & $\begin{array}{c}2.168 * * * \\
(2.72)\end{array}$ & $\begin{array}{c}-7.510 * * * \\
(-2.81)\end{array}$ & $\begin{array}{c}1.779 * * * \\
(4.47)\end{array}$ & \\
\hline City fixed effect & Yes & Yes & Yes & Yes \\
\hline Observations & 1430 & 1430 & 1430 & 1430 \\
\hline $\mathrm{R}^{2}$ & 0.13 & 0.313 & & 0.266 \\
\hline
\end{tabular}




\subsubsection{Efficiency decomposition analysis}

To further clarify the reasons why manufacturing agglomeration affects green development

516 efficiency, this paper decomposes green development efficiency into green development technology

517 efficiency (GDTC) and green development technology progress (GDTP) and uses 2SLS to re-

518 estimate the model.

\section{Table 7}

520 Estimated results in efficiency decomposition

\begin{tabular}{|c|c|c|}
\hline \multirow{2}{*}{ Variable } & Explained variable: GDTC & Explained Variable: GDTP \\
\hline & (1) & (2) \\
\hline \multirow[t]{2}{*}{ lnMA_LQ } & 0.537 & $-0.343^{*}$ \\
\hline & $(1.40)$ & $(-1.67)$ \\
\hline \multirow[t]{2}{*}{$\ln H C$} & 0.656 & -0.030 \\
\hline & $(0.93)$ & $(-0.08)$ \\
\hline \multirow[t]{2}{*}{$\operatorname{lnIND}$} & 0.076 & -0.020 \\
\hline & $(0.42)$ & $(-0.21)$ \\
\hline \multirow[t]{2}{*}{$\ln E S$} & -0.072 & $0.075 * * *$ \\
\hline & $(-1.45)$ & $(2.83)$ \\
\hline \multirow[t]{2}{*}{$\ln E R$} & -0.226 & $0.151 *$ \\
\hline & $(-1.49)$ & (1.86) \\
\hline \multirow[t]{2}{*}{$\ln T E$} & 0.026 & $-0.020^{*}$ \\
\hline & (1.34) & $(-1.88)$ \\
\hline \multirow[t]{2}{*}{$\ln P D$} & -0.044 & $0.827 * * *$ \\
\hline & $(-0.08)$ & $(2.87)$ \\
\hline City fixed effect & Yes & Yes \\
\hline $\mathrm{R}^{2}$ & -0.038 & -0.038 \\
\hline
\end{tabular}

According to column (1) of Table 7, manufacturing agglomeration has a positive effect on GDTC, but it fails the significance test. This shows that manufacturing agglomeration cannot promote GDTC effectively. From column (2) of Table 7, we can see that the regression coefficient

524 of manufacturing agglomeration is -0.343 , and it is significant under the confidence level of $10 \%$.

525 This shows that manufacturing agglomeration mainly hinders the improvement of green 526 development efficiency by inhibiting GDTP. 


\subsubsection{Regional heterogeneity analysis}

To further analyze the impact of regional heterogeneity on the relationship between manufacturing agglomeration and green development efficiency, this paper divides the YREB into 429 observations of 33 cities in the upper reaches, and 1001 observations of 77 cities in the middle and lower reaches and re-estimates model (4) by using 2SLS.

\section{Table 8}

533 Estimated results in regional heterogeneity

\begin{tabular}{ccc}
\hline \multirow{2}{*}{ Variable } & Upper reaches & Middle and lower reaches \\
\cline { 2 - 3 } & $(1)$ & $(2)$ \\
\hline InMA_LQ & $1.103^{*}$ & $-0.512^{*}$ \\
& $(1.71)$ & $(-1.87)$ \\
Control variable & Yes & Yes \\
City fixed effect & Yes & Yes \\
Observations & 429 & 1001 \\
$\mathrm{R}^{2}$ & 0.086 & 0.359 \\
\hline
\end{tabular}

It can be seen from Table 8 that the regression coefficient of manufacturing agglomeration in the upper reaches of the YREB is positive, and it has passed the significance test of $10 \%$, indicating that the manufacturing agglomeration in the upper reaches is conducive to improving green development efficiency. On the contrary, the regression coefficient of manufacturing agglomeration in the middle and lower reaches is significantly negative, indicating that deepening manufacturing agglomeration in the middle and lower reaches would hinder the improvement of green development efficiency.

\subsubsection{Spatial spillover analysis}

To analyze the spatial spillover effect of manufacturing agglomeration on green development

543 efficiency, this article uses SPDM to investigate the relationship between the two. According to the

544 Wald and LR tests (Table 9), SPDM cannot degenerate into a Spatial Panel Lag Model (SPLM) or 545 Spatial Panel Error Model (SPDM), indicating that it is reasonable to choose SPDM. 
548 Estimated results in spatial spillover effect

\begin{tabular}{|c|c|c|c|}
\hline Variable & $\mathrm{W}_{1}$ & $\mathrm{~W}_{2}$ & $\mathrm{~W}_{3}$ \\
\hline \multirow[t]{2}{*}{$\rho$} & $-0.406^{*}$ & $-0.086^{*}$ & $-0.216 * *$ \\
\hline & $(-1.91)$ & $(-1.68)$ & $(-2.53)$ \\
\hline \multirow[t]{2}{*}{ lnMA_LQ } & $-0.169 * * *$ & $-0.153 * * *$ & $-0.195 * * *$ \\
\hline & $(-3.05)$ & $(-2.80)$ & $(-3.39)$ \\
\hline \multirow[t]{2}{*}{ W*InMA_LQ } & $2.016 * * *$ & $0.646^{* * *}$ & $0.601 * * *$ \\
\hline & $(2.85)$ & $(4.81)$ & $(2.72)$ \\
\hline \multirow[t]{3}{*}{$\ln M A \_L Q$ (Direct effect) } & $-0.178 * * *$ & $-0.160 * * *$ & $-0.201 * * *$ \\
\hline & $(-3.08)$ & $(-2.89)$ & $(-3.35)$ \\
\hline & $(0.15)$ & $(2.14)$ & $(0.25)$ \\
\hline \multirow[t]{2}{*}{$\ln M A \_L Q$ (Indirect effect) } & $1.506 * * *$ & $0.610 * * *$ & $0.531 * * *$ \\
\hline & (2.69) & $(5.05)$ & $(2.81)$ \\
\hline \multirow[t]{2}{*}{$\ln M A \_L Q($ Total effect $)$} & $1.329 * *$ & $0.450 * * *$ & $0.330 *$ \\
\hline & $(2.44)$ & $(3.45)$ & $(1.94)$ \\
\hline Wald-spatial lag & $69.8715 * * *$ & $67.9820 * * *$ & $109.3534 * * *$ \\
\hline LR-spatial lag & $77.5363 * * *$ & $63.3894 * * *$ & $110.5990 * * *$ \\
\hline Wald-spatial error & $53.0476 * * *$ & $68.4285^{* * *}$ & $96.7078 * * *$ \\
\hline LR-spatial error & $91.9438 * * *$ & $69.6430 * * *$ & $116.3584 * * *$ \\
\hline Hausman test & $354.3084 * * *$ & $163.3196^{* * *}$ & $541.4046^{* * *}$ \\
\hline Control variable & Yes & Yes & Yes \\
\hline City fixed effect & Yes & Yes & Yes \\
\hline Time fixed effect & Yes & Yes & Yes \\
\hline Observations & 1430 & 1430 & 1430 \\
\hline
\end{tabular}

The regression results show that the $\rho$ coefficients of the spatial lag term under the three spatial weight matrices are always significantly negative, indicating that the improvement of local green development efficiency would be constrained by green development efficiency of neighboring regions. Under different spatial weight matrices, the estimated coefficients of manufacturing agglomeration are significantly negative, and all have passed the significance test at the level of $1 \%$. This illustrates that deepening manufacturing agglomeration would seriously hinder the improvement of green development efficiency, which is consistent with the estimation results of non-spatial panel model. However, the coefficients of the spatial lag term of the manufacturing agglomeration under the three spatial weight matrices are significantly positive, which indicates that

558 the manufacturing agglomeration can significantly promote the improvement of green development efficiency in neighboring areas.

It can be seen from the spatial effect decomposition results that the regression coefficients of 
the direct effects of manufacturing agglomeration under the three spatial weight matrices are significantly negative, and all of them have passed the significance test at the level of $1 \%$, indicating that deepening manufacturing agglomeration would reduce green development efficiency. The spatial spillover effect coefficients of manufacturing agglomeration under different spatial weight matrices are significantly positive, and all are significant at the confidence level of $1 \%$, indicating that increasing the level of local manufacturing agglomeration can help promote green development efficiency in neighboring areas.

\subsection{Robustness test}

(1) Moving average. To overcome the regression bias caused by excessive data fluctuations, this article performs a 3-year moving average on the sample observations, and then continues to reestimate the model by the 2SLS method. From column (1) of Table 10, we can see that after controlling the data fluctuation, the regression coefficient of manufacturing agglomeration is still significantly negative and has passed the significance test at the level of $1 \%$, indicating that the main conclusions of this paper are relatively robust.

(2) Increasing control variables. Since changes in meteorological factors have an important impact on pollutant emissions in a region, this paper further controls the annual average precipitation (AAP), average wind speed (AWS), average air pressure (APR), sunshine hours (SUH), relative conclusions of this article. It can be seen from column (3) of Table 10 that under the circumstance humidity (RHU) and other meteorological factors, and performs logarithmization on each variable. It can be seen from column (2) of Table 10 that after considering the interference of meteorological factors, the regression coefficient of manufacturing agglomeration is still significantly negative and is significant at the confidence level of $10 \%$, indicating that the inhibitory effect of manufacturing agglomeration on green development efficiency would remain the same regardless of the changes in weather conditions.

(3) Changing the regression method. To avoid bias caused by regression method, this section integrates GMM and instrumental variable method to re-verify the reliability of the main of changing the regression method, the manufacturing industry would still hinder the improvement of green development efficiency. This verified the reliability of the conclusions of this article again. 
(4) Replacing instrumental variables. To validate the robustness of the conclusion, this article

590

591

592

593

594

595

596

597

598

599

600

601

602

603

uses "whether each Chinese city has railways or not in 1933" (dum_rail) as an instrumental variable for manufacturing agglomeration (Lin and Tan, 2019). Based on this, this paper once again uses 2SLS to estimate the model. According to column (4) of Table 10, there is still a significant negative relationship between manufacturing agglomeration and green development efficiency. This shows that the main conclusions of this article would not change significantly due to different instrument variables.

(5) Replacing core explanatory variables. Based on the replacement of instrumental variables, this paper further uses HHI to re-measure the manufacturing agglomeration level (Mitchell, 2019). It can be seen from column (5) of Table 10 that manufacturing agglomeration has a significant hindrance to green development efficiency. This shows that the main conclusions of this article would not change significantly due to different measurement methods of manufacturing agglomeration.

\section{Table 10}

Robustness test results

\begin{tabular}{|c|c|c|c|c|c|}
\hline \multirow{2}{*}{ Variable } & \multicolumn{5}{|c|}{ Explained variable: $\operatorname{lnGDE}$} \\
\hline & (1) & (2) & (3) & (4) & (5) \\
\hline lnMA_LQ & $\begin{array}{c}-0.787 * * * \\
(-2.62)\end{array}$ & $\begin{array}{c}-0.711 * \\
(-1.93)\end{array}$ & $\begin{array}{c}-0.928 * \\
(-1.70)\end{array}$ & $\begin{array}{c}-1.102 * * * \\
(-2.68)\end{array}$ & $\begin{array}{c}-0.798 * * * \\
(-2.61)\end{array}$ \\
\hline $\ln \mathrm{HC}$ & $\begin{array}{l}-0.712 \\
(-1.21)\end{array}$ & $\begin{array}{l}-0.231 \\
(-0.38)\end{array}$ & $\begin{array}{l}-0.379 \\
(-0.59)\end{array}$ & $\begin{array}{l}-0.558 \\
(-0.86)\end{array}$ & $\begin{array}{c}-2.005^{*} \\
(-1.77)\end{array}$ \\
\hline $\operatorname{lnIND}$ & $\begin{array}{c}-1.139 * * * \\
(-8.47)\end{array}$ & $\begin{array}{c}-0.834 * * * \\
(-4.98)\end{array}$ & $\begin{array}{c}-0.957 * * * \\
(-4.57)\end{array}$ & $\begin{array}{c}-0.724 * * * \\
(-4.03)\end{array}$ & $\begin{array}{c}-0.770 * * * \\
(-3.86)\end{array}$ \\
\hline $\operatorname{lnES}$ & $\begin{array}{l}0.091 \\
(1.30)\end{array}$ & $\begin{array}{l}-0.027 \\
(-0.64)\end{array}$ & $\begin{array}{l}0.074 \\
(0.80)\end{array}$ & $\begin{array}{l}-0.023 \\
(-0.51)\end{array}$ & $\begin{array}{l}-0.019 \\
(-0.33)\end{array}$ \\
\hline $\operatorname{lnER}$ & $\begin{array}{c}0.316^{* * *} \\
(2.58)\end{array}$ & $\begin{array}{l}0.067 \\
(0.50)\end{array}$ & $\begin{array}{l}0.220 \\
(1.31)\end{array}$ & $\begin{array}{l}0.114 \\
(0.82)\end{array}$ & $\begin{array}{l}-0.192 \\
(-1.09)\end{array}$ \\
\hline $\operatorname{lnTE}$ & $\begin{array}{c}0.273 * * * \\
(15.60)\end{array}$ & $\begin{array}{c}0.248 * * * \\
(14.41)\end{array}$ & $\begin{array}{c}0.264 * * * \\
(7.65)\end{array}$ & $\begin{array}{c}0.251 * * * \\
(13.94)\end{array}$ & $\begin{array}{c}0.333 * * * \\
(8.05)\end{array}$ \\
\hline $\ln P D$ & $\begin{array}{l}0.156 \\
(0.37)\end{array}$ & $\begin{array}{c}0.908 * \\
(1.87)\end{array}$ & $\begin{array}{l}0.858 \\
(1.30)\end{array}$ & $\begin{array}{c}1.205 * * \\
(2.32)\end{array}$ & $\begin{array}{l}0.752 \\
(1.39)\end{array}$ \\
\hline Meteorological factors & No & Yes & No & Yes & No \\
\hline City fixed effect & Yes & Yes & Yes & Yes & Yes \\
\hline Time fixed effect & No & No & Yes & No & No \\
\hline Observations & 1430 & 1430 & 1430 & 1430 & 1430 \\
\hline $\mathrm{R}^{2}$ & 0.378 & 0.295 & 0.716 & 0.231 & -0.206 \\
\hline
\end{tabular}




\section{Conclusion and policy implications}

Based on a Chinese case, this article reveals how manufacturing agglomeration affects the green development efficiency from both theoretical and empirical dimensions, and scientifically measures the quantitative relationship between the two. The research shows that: First, the overall gap of green development efficiency in the YREB is relatively large, and the regional gap of the upper reaches contributes an average annual rate of $52.95 \%$ to the entire regional gap in the YREB. Second, manufacturing agglomeration in the YREB inhibits the improvement of green development efficiency and, but it has no obvious effect on GDTC. Third, manufacturing agglomeration can promote green development efficiency in upper reaches but hinder the improvement of green development efficiency in the middle and lower reaches. Fourth, manufacturing agglomeration in the YREB would also promote green development efficiency in neighboring regions. The above analysis can provide new perspectives and methods for the green transformation of the YREB and the world.

Based on the abovementioned analysis, this article proposes the following suggestions regarding the government's political design for manufacturing agglomeration to promote green development efficiency:

(1) It is necessary to focus on advancing green development efficiency in the upper reaches of the YREB and promote coordinated development within the region. Since the regional gap of the upper reaches contributes an average annual rate of more than $50 \%$ to the entire regional gap in the YREB, we must first solve the problem of green development efficiency in the upper reaches. As an ecologically vulnerable area, the ecological barrier is an important mission shouldered by the upper reaches. To this end, priority must be given to the development of ecological and environmental protection industries to meet the needs of economic and social development. Second, while the middle and lower reaches and all other regions of the country are enjoying the overflow of ecological welfare, the upper reaches should be compensated ecologically.

(2) It is necessary to stimulate the development and application of green innovative technologies. The results of this study show that manufacturing agglomeration hinders the technological progress of green development, which is an important reason for the reduction of the 
green development efficiency. Therefore, on the one hand, local governments should promote the transformation and upgrading of regional manufacturing by strengthening environmental regulations, and guide and encourage the increase in R\&D investment. On the other hand, decisionmaking departments should encourage social forces and enterprises to participate in green technological innovation, and guide enterprises to conduct green innovation activities in accordance with market demand.

(3) It is necessary to formulate differentiated agglomeration policies. As the manufacturing agglomeration can promote green development efficiency in the upper reaches yet inhibit green development efficiency in the middle and lower reaches, efforts should be taken to deepen the level and quality of manufacturing agglomeration, prevent excessive agglomeration, and maximize the economic effect of agglomeration in the upper reaches. For middle and lower reaches, it is necessary to focus on the upgrading and transformation of local manufacturing agglomeration. On the one hand, we must strictly implement environmental regulations and policies, eliminate a number of backward industries, and promote the survival of the fittest; on the other hand, we must introduce a group of green manufacturing enterprises to promote the transformation and upgrading of the local manufacturing industry.

(4) It is necessary to pay attention to the spatial spillover effect of manufacturing agglomeration and promote the regional linkage of green development efficiency in the YREB. The increase in the local manufacturing agglomeration can drive the improvement of green development efficiency in neighboring areas. Therefore, we must abandon the mindset of local protectionism, break down the administrative barriers, and allow the free flow of resources, thereby reducing the loss of spatial spillover due to space division. Besides, regional cooperation institutions and cooperation systems should be established to develop urban agglomeration economies and cross-regional economies.

Although this article has conducted an in-depth analysis of the relationship between manufacturing agglomeration and green development efficiency, there are still some aspects worth further study. Since manufacturing agglomeration mainly comprises of enterprises, quantitative analysis on micro-mechanism of the impact of manufacturing agglomeration on green development efficiency would be more politically significant for the transformation of local manufacturing 
agglomeration and global sustainable development. As China is the world's largest transitional economy, studying the relationship between China's manufacturing agglomeration and green development efficiency might shed important implications for the development of emerging countries in the world. Moreover, comparative analysis on the mechanism and effect of manufacturing agglomeration and green development efficiency between China and other typical developed economies in the world can be done to further enrich the connotation and extension of industrial agglomeration. This line of research would provide a new perspective for the green transformation of the global economy.

\section{References}

Aleksandrova, E., Behrens, K., Kuznetsova, M., 2020. Manufacturing (co)agglomeration in a transition country: Evidence from Russia. Journal of Regional Science 60, 88-128.

Balaguer, J., Cantavella, M., 2018. The role of education in the Environmental Kuznets Curve. Evidence from Australian data. Energy Economics 70, 289-296.

Beeson, P., 1987. Total factor productivity growth and agglomeration economies in manufacturing. Journal of Regional Science 27, 183-199.

Berliant, M., Reed, R.R., Wang, P., 2006. Knowledge exchange, matching, and agglomeration. Journal of Urban Economics 60, 69-95.

Brakman, S., Garretsen, H., Gigengack, R., van Marrewijk, C., Wagenvoort, R., 1996. Negative feedbacks in the economy and industrial location. Journal of Regional Science 36, 631-651.

Broersma, L., Oosterhaven, J., 2009. Regional labor productivity in the Netherlands: Evidence of agglomeration and congestion effects. Journal of Regional Science 49, 483-511.

Brülhart, M., Mathys, N.A., 2008. Sectoral agglomeration economies in a panel of European regions. Regional Science and Urban Economics 38, 348-362. 
Cai, X., Che, X., Zhu, B., Zhao, J., Xie, R., 2018. Will developing countries become pollution havens for developed countries? An empirical investigation in the Belt and Road. Journal of Cleaner Production 198, 624-632.

Charnes, A., Cooper, W.W., Rhodes, E., 1978. Measuring the efficiency of decision making units. European Journal of Operational Research 2, 429-444.

Chen, A., Dai, T., Partridge, M.D., 2020. Agglomeration and firm wage inequality: Evidence from China. Journal of Regional Science, 1-35.

Chen, D., Chen, S., Jin, H., 2018a. Industrial agglomeration and CO2 emissions: Evidence from 187 Chinese prefecture-level cities over 2005 - 2013. Journal of Cleaner Production 172, 993-1003.

Chen, D., Chen, S., Jin, H., 2018b. Industrial agglomeration and CO2 emissions: Evidence from 187 Chinese prefecture-level cities over 2005 - 2013. Journal of Cleaner Production 172, 993-1003.

Chen, L., Zhang, X., He, F., Yuan, R., 2019. Regional green development level and its spatial relationship under the constraints of haze in China. Journal of Cleaner Production 210, 376-387.

Chung, Y.H., Färe, R., Grosskopf, S., 1997. Productivity and Undesirable Outputs: A Directional Distance Function Approach. Journal of Environmental Management 51, 229-240.

Ciccone, A., 2002. Agglomeration effects in Europe. European Economic Review 46, 213-227.

Davidson, R., MacKinnon, J.G., 1993. Estimation and Inference in Econometrics, $2^{\text {nd }}$ ed ed. Oxford University Press, Oxford.

Duranton, G., Puga, D., 2004. Chapter 48 - Micro-foundations of urban agglomeration economies, in: Henderson, J.V., Thisse, J. (Eds.), Handbook of Regional and Urban Economics. Elsevier, 2063-2117.

Erdogan, S., 2020. Analyzing the environmental Kuznets curve hypothesis: The role of disaggregated transport infrastructure investments. Sustainable Cities and Society 61, 102338.

Fang, J., Tang, X., Xie, R., Han, F., 2020. The effect of manufacturing agglomerations on smog pollution. Structural 
Feng, Y., Wang, X., Du, W., Wu, H., Wang, J., 2019. Effects of environmental regulation and FDI on urban innovation in China: A spatial Durbin econometric analysis. Journal of Cleaner Production 235, 210-224.

Gopinath, M., Pick, D., Li, Y., 2004. An empirical analysis of productivity growth and industrial concentration in us manufacturing. Applied Economics 36, 1-7.

Graham, D.J., 2009. Identifying urbanisation and localisation externalities in manufacturing and service industries*. Papers in Regional Science 88, 63-84.

Grant, R.M., 1996. Toward a knowledge-based theory of the firm. Strategic Management Journal 17, 109-122.

Guliyev, H., 2020. Determining the spatial effects of COVID-19 using the spatial panel data model. Spatial Statistics $38,100443$.

He, Y., Cheng, X., Wang, F., Cheng, Y., 2020. Spatial correlation of China' s agricultural greenhouse gas emissions: a technology spillover perspective. Natural Hazards 104, 2561-2590.

Henderson, J.V., 2003. Marshall's scale economies. Journal of Urban Economics 53, 1-28.

Hong, C., Zhang, Q., Zhang, Y., Davis, S.J., Zhang, X., Tong, D., Guan, D., Liu, Z., He, K., 2020. Weakening aerosol direct radiative effects mitigate climate penalty on Chinese air quality. Nature Climate Change 10, 845850.

Hu, C., Xu, Z., Yashiro, N., 2015. Agglomeration and productivity in China: Firm level evidence. China Economic Review 33, 50-66.

Huang, J., Zou, H., Song, Y., 2021. Biased technical change and its influencing factors of iron and steel industry: Evidence from provincial panel data in China. Journal of Cleaner Production 283, 124558.

Jin, P., Peng, C., Song, M., 2019. Macroeconomic uncertainty, high-level innovation, and urban green development performance in China. China Economic Review 55, 1-18. 
Klein, N., Herwartz, H., Kneib, T., 2020. Modelling regional patterns of inefficiency: A Bayesian approach to geoadditive panel stochastic frontier analysis with an application to cereal production in England and Wales. Journal of Econometrics 214, 513-539.

Kopczewska, K., Kudła, J., Walczyk, K., 2017. Strategy of spatial panel estimation: Spatial spillovers between taxation and economic growth. Applied Spatial Analysis and Policy 10, 77-102.

Korhonen, P.J., Luptacik, M., 2004. Eco-efficiency analysis of power plants: An extension of data envelopment analysis. European Journal of Operational Research 154, 437-446.

Li, X., Lai, X., Zhang, F., 2021. Research on green innovation effect of industrial agglomeration from perspective of environmental regulation: Evidence in China. Journal of Cleaner Production 288, 125583.

Liang, Z., Lei, C., Chenghu, Z., 2019. Spatio-temporal evolution and influencing factors of urban green development efficiency in China. Acta Geographica Sinica 74, 2027-2044.

Lin, B., Benjamin, N.I., 2017. Green development determinants in China: A non-radial quantile outlook. Journal of Cleaner Production 162, 764-775.

Lin, B., Tan, R., 2019. Economic agglomeration and green economy efficiency in China. Economic Research Journal, $119-132$

Lin, H., Li, H., Yang, C., 2011. Agglomeration and productivity: Firm-level evidence from China's textile industry. China Economic Review 22, 313-329.

Liu, S., Xiao, W., Li, L., Ye, Y., Song, X., 2020. Urban land use efficiency and improvement potential in China: A stochastic frontier analysis. Land Use Policy 99, 105046.

Long, R., Ouyang, H., Guo, H., 2020. Super-slack-based measuring data envelopment analysis on the spatial temporal patterns of logistics ecological efficiency using global Malmquist Index model. Environmental Technology \& Innovation 18, 100770. 
Lu, J., Li, B., Li, H., Al-Barakani, A., 2021. Expansion of city scale, traffic modes, traffic congestion, and air pollution. Cities 108, 102974.

Lv, Y., Chen, W., Cheng, J., 2020. Effects of urbanization on energy efficiency in China: New evidence from short run and long run efficiency models. Energy Policy 147, 111858.

Managi, S., Kumar, S., 2009. Trade-induced technological change: Analyzing economic and environmental outcomes. Economic Modelling 26, 721-732.

Marshall, A., 1920. Principles of economics. Macmillan, London.

Miao, Z., Baležentis, T., Tian, Z., Shao, S., Geng, Y., Wu, R., 2019. Environmental performance and regulation effect of China' s atmospheric pollutant emissions: Evidence from “ Three Regions and Ten Urban Agglomerations” . Environmental and Resource Economics 74, 211-242.

Mitchell, S., 2019. London calling? Agglomeration economies in literature since 1700. Journal of Urban Economics $112,16-32$.

Mohtadi, H., 1996. Environment, growth, and optimal policy design. Journal of Public Economics 63, 119-140.

Nunn, N., Qian, N., 2014. US food aid and civil conflict. American Economic Review 104, 1630-1666.

Overman, H.G., Puga, D., 2010. Labor pooling as a source of agglomeration: An empirical investigation. CEPR Discussion Papers, pp. 133-150.

Qiu, Y.Q., Zhou, P., Sun, H.C., 2019. Assessing the effectiveness of city-level electric vehicle policies in China. Energy Policy 130, 22-31.

Qu, C., Shao, J., Shi, Z., 2020. Does financial agglomeration promote the increase of energy efficiency in China? Energy Policy 146, 111810.

Raiher, A.P., 2019. Economies of agglomeration and their relation with industrial productivity in Brazilian municipalities. Papers in Regional Science 99(3): 725-747. 
Ramanathan, R., 2005. An analysis of energy consumption and carbon dioxide emissions in countries of the Middle East and North Africa. Energy 30, 2831-2842.

Rizov, M., Oskam, A., Walsh, P., 2012. Is there a limit to agglomeration? Evidence from productivity of Dutch firms. Regional Science and Urban Economics 42, 595-606.

Sarkodie, S.A., Ozturk, I., 2020. Investigating the Environmental Kuznets Curve hypothesis in Kenya: A multivariate analysis. Renewable and Sustainable Energy Reviews 117, 109481.

Shao, S., Yang, L., Yu, M., Yu, M., 2011. Estimation, characteristics, and determinants of energy-related industrial CO2 emissions in Shanghai (China), 1994 - 2009. Energy Policy 39, 6476-6494.

Shuai, S., Fan, Z., 2020. Modeling the role of environmental regulations in regional green economy efficiency of China: Empirical evidence from super efficiency DEA-Tobit model. Journal of Environmental Management $261,110227$.

Song, M., Zhao, X., Shang, Y., Chen, B., 2020. Realization of green transition based on the anti-driving mechanism: An analysis of environmental regulation from the perspective of resource dependence in China. Science of the Total Environment 698, 134317.

Theil, H., Uribe, P., 1967. The Information Approach to the Aggregation of Input-Output Tables. The Review of Economics and Statistics 49, 451-462.

Tone, K., 2001. A slacks-based measure of efficiency in data envelopment analysis. European Journal of Operational Research 130, 498-509.

Tone, K., 2002. A slacks-based measure of super-efficiency in data envelopment analysis. European Journal of Operational Research 143, 32-41.

Wang, J., Zhang, L., Niu, X., Liu, Z., 2020. Effects of PM2.5 on health and economic loss: Evidence from BeijingTianjin-Hebei region of China. Journal of Cleaner Production 257, 120605. 
Wang, Y., He, X., 2019. Spatial economic dependency in the Environmental Kuznets Curve of carbon dioxide: The case of China. Journal of Cleaner Production 218, 498-510.

Wei, Z., Han, B., Pan, X., Shahbaz, M., Zafar, M.W., 2020. Effects of diversified openness channels on the totalfactor energy efficiency in China's manufacturing sub-sectors: Evidence from trade and FDI spillovers. Energy Economics 90, 104836.

World Bank, 2017. <https://data.worldbank.org/indicator>.

Wu, H., Li, Y., Hao, Y., Ren, S., Zhang, P., 2020. Environmental decentralization, local government competition, and regional green development: Evidence from China. Science of the Total Environment 708, 135085.

Xing, J., Lu, X., Wang, S., Wang, T., Ding, D., Yu, S., Shindell, D., Ou, Y., Morawska, L., Li, S., Ren, L., Zhang, Y., Loughlin, D., Zheng, H., Zhao, B., Liu, S., Smith, K.R., Hao, J., 2020. The quest for improved air quality may push China to continue its CO\&lt;sub\&gt;2\&lt;/sub\&gt; reduction beyond the Paris Commitment. Proceedings of the National Academy of Sciences 117, 29535.

Yin, H., Brauer, M., Zhang, J.J., Cai, W., Navrud, S., Burnett, R., Howard, C., Deng, Z., Kammen, D.M., Schellnhuber, H.J., Chen, K., Kan, H., Chen, Z., Chen, B., Zhang, N., Mi, Z., Coffman, D., Cohen, A.J., Guan, D., Zhang, Q., Gong, P., Liu, Z., 2021. Population ageing and deaths attributable to ambient PM2.5 pollution: a global analysis of economic cost. The Lancet Planetary Health 5, e356-e367.

Yu, X., Wang, P., 2021. Economic effects analysis of environmental regulation policy in the process of industrial structure upgrading: Evidence from Chinese provincial panel data. Science of the Total Environment 753, 142004.

Yuan, B., Xiang, Q., 2017. Environmental regulation, industrial innovation and green development of Chinese manufacturing: Based on an extended CDM model. Journal of Cleaner Production 176, 895-908.

Yuan, H., Feng, Y., Lee, C., Cen, Y., 2020. How does manufacturing agglomeration affect green economic efficiency? 
Yuan, H., Feng, Y., Lee, J., Liu, H., Li, R., 2020. The spatial threshold effect and its regional boundary of financial agglomeration on green development: A case study in China. Journal of Cleaner Production 244, 118670.

821 Zeng, W., Li, L., Huang, Y., 2021. Industrial collaborative agglomeration, marketization, and green innovation: Evidence from China's provincial panel data. Journal of Cleaner Production 279, 123598.

Zhang, J., Qu, X., Sangaiah, A.K., 2018. A Study of Green Development Mode and Total Factor Productivity of the Food Industry Based on the Industrial Internet of Things. IEEE Communications Magazine 56, 72-78. delta region of China. Journal of Environmental Management 261, 110208. on China's green development efficiency: A novel integrated approach. Energy Economics, 104601. 